\title{
PENGARUH LATIHAN BEBAN MENGGUNAKAN KARET TERHADAP HASIL TENDANGAN DALAM PERMAINAN SEPAK BOLA PADA SISWA PUTRA KELAS VIII SMP NEGERI 1 INDRALAYA SELATAN
}

\author{
Novri Asri \\ Universitas Islam Kalimantan Muhammad Arsyad Al Banjari Banjarmasin \\ Novriasri.na@gmail.com
}

\begin{abstract}
ABSTRAK
Penelitian ini berjudul pengaruh latihan beban menggunakan karet terhadap hasil tendangan dalam permainan sepak bola pada siswa putra kelas VIII SMP Negeri 1 Indralaya Selatan. Penelitian ini dilaksanakan pada tanggal 01 September sampai dengan 10 Oktober 2018. Penelitian ini termasuk penelitian eksperimen dengan menggunakan rancangan pretest-posttest control group design dengan variabel bebas latihan beban menggunakan karet, variabel terikat hasil tendangan dalam permainan sepak bola. Subjek dalam penelitian ini adalah siswa putra kelas VIII siswa yang dipilih dengan teknik Sampling. Penelitian ini bertujuan untuk mengetahui seberapa besar pengaruh latihan beban menggunakan karet terhadap hasil tendangan dalam permainan sepak bola pada siswa putra kelas VIII SMP Negeri 1 Indralaya Selatan, untuk menentukan kelompok eksperimen dan kontrol peneliti menggunakan teknik simple random sampling dengan sistem ordinal pairing. Metode pengumpulan data yang digunakan adalah tes, pada setiap kelompok ,tes diberikan di awal sebelum perlakuan dan di akhir setelah diberi perlakuan. Perlakuan di kelompok eksperimen berupa latihan beban menggunakan karet, Setelah diberikan perlakuan selama 6 minggu dengan frekuensi latihan 3 kali seminggu. Berdasarkan analisis data dengan cara statistik uji t dengan taraf signifikan $\alpha=0,05$ di dapat $\mathrm{t}$ hitung $=31,92$ dan $\mathrm{t}$ tabel $=1,67$, apabila thitung $>$ ttabel maka Ha diterima dan Ho ditolak. Dengan demikian Ha yang diajukan dapat diterima kebenarannya, bahwa latihan beban menggunakan karet berpengaruh terhadap hasil tendangan dalam permaina sepak bola pada siswa putra kelas VIII SMP Negeri 1 Indralaya Selatan.
\end{abstract}

Kata kunci: Latihan Beban Menggunakan Karet, Hasil Tendangan, Sepak Bola.

\section{ABSTRACT}

This research entitled the influence training of weight using the rubber against the result kicks in the game of football for a men student class VIII junior high school number 1 South Indralaya. This research was carried out on the date 01 September until 10 October 2018. This research is a experiments research using a pretest-posttest design control group design, with training using of weight the rubber is a independen variable or variable free and variable bound is a result kicks in the game of football. The subject in this research is a men student class VIII selected with Sampling technic. This research aims of is to figure out how big the influence of weight training using the rubber against the result kicks in the game of football for a men student class VIII junior high school number 1 South Indralaya, to determine experimental groups and groups control of researchers using simple random sampling with the ordinal pairing system. The data collection method used is the test on each group, a test is given at the beginning before treatment and at the end after being given the treatment. Treatment of experimental groups in the form of weight training using rubber, after being given treatment for 6 weeks with the frequency of exercise 3 times on a week. Based on analysis of data by means of the t-test statistical significant level $\alpha=0,05$ in can $t$ calculate $=31.92$ and ttable $=1.67$, when thitung $>$ ttabel then Ha Ho accepted and rejected. Thus Ha put forward can be accepted, training of weight using the rubber influential on results of kicks in the game of football a men student class VIII junior high school number 1 South Indralaya.

Keywords: weight training using rubber, the results kick, football.

Dipublikasikan Oleh :

UPT Publikasi dan Pengelolaan Jurnal

Universitas Islam Kalimantan Muhammad Arsyad Al-Banjari Banjarmasin 


\section{Pendahuluan}

Sepak bola merupakan permainan beregu, masing-masing regu terdiri dari 11 pemain. Permainan ini hampir seluruhnya dimainkan menggunakan tungkai, kadangkala menggunakan kepala dan dada, untuk penjaga gawang diperbolehkan menggunakan tangan dan lenganya di daerah tendangan hukuman. Permainan sepak bola dapat dilakukan di lapangan terbuka (out door) dan dilapangan tertutup (in door), adapun tujuan permainan sepak bola adalah pemain berusaha memasukan bola sebanyak-banyaknya ke gawang lawan dan berusaha menjaga gawangnya sendiri agar tidak kemasukan bola, suatu regu dapat dinyatakan menang apabila dapat memasukan bola terbanyak ke gawang lawanya tetapi apabila hasil sama (misalnya 0-0 atau 1-1, 2-2 dan seterusnya) maka permainan dapat dinyatakan seri atau draw, atau diberi tambahan waktu, dan adu penalti.

Permainan sepak bola adalah permainan yang berusaha menggiring bola ke pihak lawan, ada dugaan orang-orang Romawi membawa permainan itu ke Inggris, kemudian Inggris memulai mengembangkan permainan ini dengan sempurna sehingga menjadi permainan sepak bola yang sekarang, tanggal 26 Oktober 1863 berdirilah The Football Association di london, organisasi ini menyusun permainan sepak bola, pada tanggal 21 Mei 1904, berdiri pula Federasi sepak bola internasional (FIFA) di Paris kemudian pada tahun 1930 Julius Rimet menyelengarakan kejuaran dunia pertama yang bertempat di Uruguay, dari sudut pandang penyerangan dalam permainan sepak bola penguasaan keterampilan teknik dasar bagi seorang pemain sepak bola adalah penting, karena sangat berkaitan dengan tujuan permainan sepak bola yaitu memasukkan bola ke gawang lawan dan mempertahankan gawang sendiri dari serangan lawan. Tanpa penguasaan teknik yang memadai maka tujuan permainan sepak bola cenderung tidak akan tercapai. Menendang bola merupakan salah satu teknik yang harus dikuasai oleh seorang pemain sepak bola, karena berdasarkan fungsinya, menendang bola dapat digunakan sebagai cara memberikan (mengoper) bola kepada teman dalam berbagai jarak dan menembak bola ke gawang. Jika kemampuan menendang bola ini kurang baik maka seorang pemain dapat dikatakan tidak dapat bermain sepak bola dengan baik.

Berdasarkan observasi yang telah dilakukan di SMP Negeri 1 Indralaya Selatan, terutama pada siswa putra kelas VIII dalam pembelajaran pada permainan sepak bola, teknik dasar menendang dalam permainan sepak bola belum sepenuhnya dikuasai dengan baik, dari exspolosive power maupun cara melakukanya, sehingga di butuhkan latihan-latihan untuk menunjang siswa dalam meningkatkan hasil tendangan dan kurang beraninya siswa melakukan tendangan langsung ke arah gawang, serta ketika melakukan tendangan ke arah gawang banyak tendangan yang tidak sampai ke gawang, dan kurang ketepatan tendangan, karena kondisi fisik siswa yang melemah ketika beberapa kali saja melakukan tendangan, menendang bola merupakan teknik dasar bermain sepak bola yang paling banyak digunakan dalam permainan sepak bola, kesebelasan sepak bola yang baik adalah suatu kesebelasan sepak bola yang semua pemainnya menguasai teknik dasar menendang bola dengan baik, cepat dan tepat ke arah sasaran, baik teman maupun sasaran dalam membuat gol ke gawang lawan. Latihan beban menggunakan karet adalah salah satu latihan yang dilakukan secara individu, dengan cara menggunakan seutas karet, yang salah satunya ujung keret diikatkan pada benda yang tak bergerak (pagar halaman atau sejenisnya) dan ujung satunya diikatkan di salah satu bagian tangan atau kaki yang digunakan untuk latihan.

Berdasarkan uraian diatas peneliti tertarik untuk mengadakan penelitian di SMP Negeri 1 Indralaya Selatan tentang "pengaruh latihan beban menggunakan karet terhadap hasil tendangan dalam permainan sepak bola pada siswa purta kelas VII SMP Negeri 1 Indralaya Selatan"

\section{TINJAUAN TEORETIS}

Sepak bola adalah salah satu olahraga yang sangat populer didunia, yang dimainkan oleh dua tim/ kelompok yang berlawanan yang masing-masing tim berjuang untuk memasukkan bola kegawang tim lawan Ridwan dan Sulaeman (2008:14). Sepak bola adalah permainan beregu yang masing-masing regu terdiri dari 11 pemain dan biasanya dimainkan dalam dua babak (2x45 menit) dengan waktu istirahat 10 menit diantara kedua babak terdebut Muhajir (2007:1). Jadi dapat disimpulkan bahwa permainan sepak bola adalah permainan yang dimainkan oleh dua tim yang saling berhadapan dengan masing-masing tim berjumlah 11 orang pemain dengan tujuan mencetak gol sebanyak - banyaknya ke gawang lawan.

Menurut Djezzed dan Darwis (1999:51-52) menendang merupakan suatu usaha untuk memindahkan bola dari satu tempat ketempat lain dengan menggunakan kaki. Menendang bola dapat dilakukan menggunakan kaki atau bagian kaki. Menendang bola dapat dilakukan dalam keadaan bola diam, menggelinding maupun melayang di udara, tujuan dari menendang bola adalah 1) untuk memberikan bola pada teman, 2) memasukan bola ke gawang, 3) untuk menghidupkan bola kembali, setelah terjadi suatu pelanggaran seperti tendangan bebas, tendangan penjuru, tendangan hukuman, tendangan gawang dan sebagainya, 4) untuk melakukan clearing atau pembersihan dengan jalan menyapu bola yang berbahaya di daerah sendiri atau dalam usaha membendung

Dipublikasikan Oleh :

UPT Publikasi dan Pengelolaan Jurnal

Universitas Islam Kalimantan Muhammad Arsyad Al-Banjari Banjarmasin 
serangan lawan pada daerah pertahan sendiri. Meurut Yulifri dan Arsil (2011:82-83-84) menendang merupakan suatu usaha untuk memindahkan bola dari suatu tempat lain dengan menggunakan kaki atau bagian kaki.

Menurut Harsono (1988:1830) latihan beban juga dapat mempergunakan alat-alat seperti katrol, karet, dan lain-lain alat untuk bisa diterapkan untuk latihan beban. Latihan beban dalam penelitian ini menggunakan seutas karet, yang salah satunya ujung keret diikatkan pada benda yang tak bergerak (pagar halaman atau sejenisnya) dan ujung satunya diikatkan disalah satu kaki yang digunnakan unuk melakukan tendangan, sarana dan prasarana yang dibutuhkan dalam latihan ini adalah: 1) karet, 2) pagar halaman, 3) pluit, 4) sepatu bola, adapun cara melakukan latihan beban menggunakan karet :

1.Sikap awal

Berdiri membelakanggi tiang gawang sejauh kurang lebih 1,5 meter, salah satu kaki diikatkan disalah satu ujung karet, dan salah satu ujung karet diikatkan di pagar halaman.

2.Pelaksanaan

Menarik karet kedepan sama seperti saat melakukan tendangan, gerakan dilakukan secara berulangulang sesuai repetesi dan volume yang di tentukan peneliti.

Daya ledak otot (eksplosive power) adalah kinerja yang dapat dilakukan dalam satu kesatuan waktu. Otot otot penunjang daya ledak otot tungkai. Sedangkan menurut (Sayoto, 1988:55) daya ledak atau power adalah kemapuan melakukan gerakan exsplosive. Power adalah hasil perkalian kekuatan maksimal (force). Dalam kehidupan sehari-hari orang selalu menggunakan tungkai bawah, baik saat berjalan, berlari maupun melompat orang selalu menggunakan dua otot yang terpenting pada betis, yaitu gastroknemius dan soleus kedua tersebut bertugas membengkokan lutut dan kaki bergerak menujuk.

Kekuatan adalah komponen kondisi fisik seseorang tentang kemampuanya dalam menggunakan otot untuk menerima beban sewaktu bekerja. Adalah urat yang besar atau jaringan kenyal di tubuh manusia untuk menggerakan orga tubuh, sedangkan tungkai adalah bagian tubuh di bawah pinggang. Berdasarkan penelitian ini yang dimaksud dengan kekuatan otot tungkai adalah gerakan-gerakan kontraksi otot kaki dalam melakukan gerakan pada waktu melakukan tendangan. Sayoto (1989:16). mengatakan kekuatan adalah komponen kondisi fisik seseorang tentang kemapuan dalam menggunakan otot untuk menerima beban sewaktu bekerja. Dari beberapa pendapat tersebut dapat disimpulkan bahwa kekuatan adalah kemapuan otot atau sekelompoknya dalam usahanya menahan beban atau pekerjaan dalam waktu yang relatif pendek.

Harsono (1988:101) menyatakan bahwa latihan adalah proses yang sistematis dari aktivitas kerja, yang dilakukan secara berulang-ulang, dengan prinsip kian hari kian bertambah bebannya, menurut Sukirno dan Waluyo (2012:103) latihan adalah suatu proses pekerjaan dalam suatu kegiatan yang dilakukan dengan berulang - ulang dengan beban meningkat untuk menghasilkan kinerja yang optimal, menurut Iyakrus (2010:73) latihan adalah aktivitas olahraga yang sistematis dalam jangka waktu yang panjang yang ditingkatkan secara progresif dan individual yang ditujukan pada pembentukan fungsi fisiologis dan psikologis manusia untuk memenuhi tuntunan tugas.

\section{METODE}

Penelitian ini menggunakan metode penelitian eksperimen. Metode eksperimen adalah suatu cara untuk mencari hubungan sebab akibat (hubungan kausal) antara dua faktor yang sengaja ditimbulkan oleh peneliti dengan mengeliminisasi atau mengurangi atau menyisihkan faktor-faktor lain yang bisa menggangu, eksperimen selalu dilakukan dengan maksud untuk melihat akibat dari suatu perlakuan (Arikunto, 2010: 9).

Menurut Sugiyono (2012:60) variable adalah segala sesuatu yang berbentuk apa saja yang ditetapkan oleh peneliti untuk dipelajari sehingga diperoleh informasi tentang hal tersebut, kemudian ditarik kesimpulanya.

1. Variabel bebas $(\mathrm{X})$ : Latihan beban menggunakan karet

2. Variabel terikat (Y) : Hasil Tendangan

Penelitian ini termasuk penelitian eksperimen, hal ini dikarenakan pengentasan bertujuan untuk mengetahui sejauh mana pengaruh latihan beban menggunakan karet yakni variabel bebas (X) terhadap hasil tendangan yakni variabel terikat (Y). Secara Fisiologi latihan dapat dilihat dari hasil dan pengaruhnya dalam jangka waktu 6-8 minggu dengan frekuensi minimal 3 kali seminggu (Harsono, 1993).

\section{HASIL DAN PEMBAHASAN}

Penelitian ini dilaksanakan di SMP Negeri 1 Indralaya Selatan,sampel penelitian yang di ambil adalah siswa putra kelsa VIII yang berjumlah 60 siswa, yang dibagi menjadi dua kelompok dengan cara ordinal pearing,

Dipublikasikan Oleh :

UPT Publikasi dan Pengelolaan Jurnal

Universitas Islam Kalimantan Muhammad Arsyad Al-Banjari Banjarmasin 
maka didapat 30 siswa kelompok eksperimen dan 30 siswa kelompok kontrol. seperti yang terlihat pada tabel dibawah ini:

Tabel Sampel Penelitian

\begin{tabular}{|l|l|l|l|}
\hline No & Jumlah & Jenis Kelamin & Kelompok \\
\hline 1 & 30 siswa & Putra & Eksperimen \\
\hline 2 & 30 siswa & Putra & Kontrol \\
\hline
\end{tabular}

Selanjutnya kelompok eksperimen diberi perlakuan berupa latihan beban menggunakan karet selama 6 minggu dengan frekuensi latihan 3 kali dalam seminggu dengan intensitas 60-70\%. Sedangkan kelompok kontroltidak diberi perlakuan.Setelah 6 minggu latihan dilakukan tes akhir (Posttest) terhadap dua kelompok.

\section{PENUTUP}

Simpulan

Berdasarkan data hasil penelitian, maka dapat diambil kesimpulan bahwa latihan beban menggunakan karet selam enam minggu dengan frekuensi latihan tiga kali seminggu berpengaruh signifikan terhadap hasil tendangan dalam permainan sepak bola pada siswa putra kelas VIII SMP Negeri 1 Indralaya Selatan.

Saran

1.Bagi Sekolah

Diharapkan dengan diadakannya penelitian tentang pengaruh latihan beban menggunakan karet terhadap hasil tendangan dalam permainan sepak bola bisa memberikan sumbangan positif bagi lembaga akademis yang terkait, khususnya dalam meningkatkan kemampuan siswa yang mengikuti pembelajaran dan penelitian.

2.Bagi Guru Penjaskes

Penelitian ini diharapkan memberikan masukan kepada para pembina olahraga khususnya guru Penjaskes dan para pemangku kepentingan lain, sebagai bahan masukan untuk dasar proses penentuan program belajar maupun dalam melatih.

3.Bagi Siswa

Diharapkan dengan diadakannya penelitian ini, para siswa dapat melakukan tendangan dengan tehnik yang benar dan memiliki eksplosive power saat melakukan tendangan.

\section{REFERENSI}

Arikunto,Suharsimi. 2006. Prosedur Penelitian Suatu Pendekatan Praktik. Jakarta: Rineka Cipta.

Bompa. O Tudor. 1994. Theory and Methodology Of Trainning. Dubuque Lowa: Kendall/Publishing Company.

Ismaryati. 2008. Tes dan Pengukuran Olahraga. Surakarta: LPP UNS dan UNS Press.

Ridwan dan Sulaeman. 2008. Sepak Bola: PT Widya Duta.

Mielke. Danny.2007.Dasar - Dasar Sepak Bola. Bandung: PT Intan Jaya Sejati.

Muhajir.2006.Pendidikan Jasmani Olahraga Dan Kesehatan: Erlangga.

Nurhasan.2001.Tes dan Pengukuran Dalam Pendidikan Jasmani. Jakarta: Direktorat Jendral Olahraga.

Sudjana. 1996. Metoda Statistika: Bandung: Tarsito.

Sugiyono. 2006. Statistik Untuk Penelitian. Bandung: CV Alfabeta.

Sugiyono.2012. Metode Penelitian Kuantitatif Kualitatif Dan $R \& D$. Bandung: alfabeta

Sukirno dan Waluyo. 2012. Cabang Olahraga Bola Voli. Palembang: Universitas Sriwijaya.

Dipublikasikan Oleh :

UPT Publikasi dan Pengelolaan Jurnal

Universitas Islam Kalimantan Muhammad Arsyad Al-Banjari Banjarmasin 
Suryabrata. 2010. Metodologi Penelitian. Jakarta: PT Grafindo.

Yulifri dan Arsil. 2011.Permainan Sepak bola. Padang: Fakultas Ilmu Keolahragaan Universitas Negeri Padang. 